\title{
KERJASAMA ANTAR UMAT BERAGAMA: Studi Rekonsiliasi Konflik Agama di Maluku dan Tual
}

\author{
Yunus Rahawarin \\ Universitas Pattimura Ambon \\ nizar_dia@yahoo.co.id
}

\begin{abstract}
Abstrak
Di penghujung pemerintahan Orde Baru, Indonesia dihadapkan pada berbagai konflik mulai dari konflik antar etnis Madura dan Dayak di Sampit dan Sambas (Kalimantan), konflik antar umat Islam dan Kristen di Poso (Sulawesi), dan berlanjut pada konflik agama di Ambon Maluku pada tahun 1999. Tulisan ini menganalisis model atau bentuk kerjasama antar umat beragama di Maluku dan Tual pasca terjadinya konflik 1999. Hasil penelitian menunjukkan bahwa pendekatan represif atau keamanan dalam usaha meminimalisasi konflik agama dan mendamaikan kedua kelompokyang bertikai di wilayah tersebut tersebut sama sekali tidak tepat Hal ini dikarenakan konflik yang terjadi di Maluku dan Tual memiliki dimensi konflik yang sangat kompleks, sehingga upaya resolusi konflik tidak bisa hanya terbatas pada upaya-upaya penghentian kekerasan dan peleraian semata, namun juga membutuhkan rekonstruksi sosial dan penguatan identitas lokal yang ada di kedua wilayah tersebut.
\end{abstract}

\begin{abstract}
COOPERATIONAMONGRELIGIOUSPEOPLES:ASTUDYOFRECONCILIATION OF POST-RELIGIOUS CONFLICTS IN MALUKU AND TUAL: At the end of the New Order regime, Indonesia faced with various conflicts, ranging from the conflicts between the Madurese and Dayak ethnic in Sampit and Sambas (Borneo), to the conflicts between Muslims and Christians in Poso (Sulawesi) and in Ambon, Maluku in 1999. This paper analyzes the model or the form of cooperation between religious communities in Maluku and Tual after the conflicts of 1999. The study reveals that the repressive and security approach in efforts to minimize religious conflict and to reconcile the
\end{abstract}


two warring parties in the region was completely inappropriate as the conflicts in Maluku and Tual were complex and multi-dimensional. The conflict resolution efforts, therefore, can not be confined to the efforts of the cessation of violence and reconciliation alone, but it also requires a social reconstruction and strengthening of local identities existing in the regions.

Kata Kunci : Konflik Agama, Rekonsiliasi, Maluku, Tual

\section{A. Pendahuluan}

Konflik Maluku 1999 adalah tragedi kemanusiaan terbesar dalam sejarah hubungan antar umat beragama di Indonesia. Konflik tersebut patut dicatat sebagai peristiwa terburuk dalam lembaran sejarah hubungan sosial bermasyarakat dan beragama di Indonesia. Konflik Maluku telah mencabik urat akar dasar kemanusiaan. Peristiwa hitam ini bukan saja telah menghancurkan relasi, struktur dan sistem sosial masyarakatnya seperti jatuhnya korban jiwa, harta benda yang tak terkira, tetapi juga telah meluluhlantakkan bangunan sendi etika, norma dan moral kemanusiaan sebagai nilai universal tertinggi yang menjadi pijakan manusia dalam kehidupan.

Berdasarkan pada pengalaman konflik 1999, masyarakat Maluku menggantung harapan agar konflik tidak lagi terjadi. Bagi mereka, peristiwa konflik Maluku cukup sekali tahun 1999 dan tidak pernah terjadi lagi. Karena itu, perlu dilakukan upaya rekonsiliasi sosial dengan menata dan membangun kembali relasi sosial serta nilai-nilai kemanusiaan yang telah hancur akibat konflik tersebut dengan menjadikan agama sebagai pijakan dasar. Mengapa harus agama? Hal ini terutama, karena konflik Maluku 1999 secara umum sering difahami sebagai konflik agama. Pandangan umum masyarakat Maluku ini memang tidak sepenuhnya benar, akan tetapi juga tidak sepenuhnya salah. Konflik tersebut, meski tidak didasari oleh masalah agama, akan tetapi agama telah terlibat dalam konflik yang pernah terjadi sebagaimana juga telah tercatat dalam hubungan antar umat beragama dalam sejarah Maluku. Agama telah berperan penting dalam perjalanan konflik sekaligus perdamaian di Maluku.

Barangkali, pasca disepakatinya perjanjian damai dalam Perjanjian Malino II tahun 2002, secara umum kondisi hubungan 
sosial dan kehidupan beragama masyarakat Maluku dapat disebut telah normal dan pulih kembali. Akan tetapi kondisi normal dan pulih tersebut jika kita telusuri secara mendalam tidak lantas membuat masyarakat Maluku merasa aman dalam menjalani kehidupannya. Rasa khawatir, curiga-mencurigai justru masih menjadi bagian dari kehidupan masyarakat beragama di Maluku. Konflik sporadis yang terjadi akhir-akhir ini di Ambon, seperti konflik politik dan perkelahian pemuda sangat dikhawatirkan akan membangkitkan kembali memori konflik 1999 dimana agama terseret dan masuk dalam konflik tersebut.

Faktor lain mengapa rasa khawatir dan curiga-mencurigai ini dapat dipahami, salah satunya adalah dilihat dari letak geografis pemukiman penduduk di Ambon misalnya, segregasi berdasar agama dapat dianggap lebih buruk dibanding sebelum konflik terjadi di tahun 1999. Wilayah utara dihuni oleh penduduk beragama Islam dan wilayah di sebelah selatan dihuni oleh mereka yang beragama Kristen. Segregasi sosial berdasar pada batas-batas kewilayahan ini menjadikan masyarakat Maluku, khususnya Ambon, sulit berintegrasi.

Pada kaitan ini, setelah satu dasawarsa berlalu, ternyata konflik dan kekerasan Maluku masih menunjukkan sifat latennya sehingga kondisi damai yang terjadi ini masih sangat rentan dan sangat memungkinkan untuk konflik terjadi kembali. Oleh karena itu, perlu segera dilakukan upaya fundamental untuk membangun kembali tatanan sosial masyarakatnya yang telah hancur ini dengan harapan agar konflik dan kekerasan yang pernah terjadi tidak terulang dimasa mendatang dengan menengok kembali seraya mengevaluasi apakah upaya-upaya penyelesaian konflik yang pernah dan sedang dilakukan telah sesuai dengan apa yang niscaya dilakukan. Sebab, disadari maupun tidak, konflik Maluku yang terjadi berkepanjangan ini telah menyeret dan melibatkan semua unsur didalamnya, termasuk agama. Selain faktor segregasi sosial kewilayahan berdasar agama, terseretnya agama selama konflik Maluku 1999 menjadikan integrasi sosial masyarakatnya semakin sulit terwujud sebagaimana sediakala sebagaimana sebelum konflik terjadi.

Tentang konflik yang berakibat pada terseretnya semua 
unsur, salah satu diantaranya agama di Maluku, hal ini dapat dilihat dari fase dan eskalasi konflik. Fase konflik, sebagaimana telah ditulis oleh banyak peneliti, konflik Maluku terbagi dalam beberapa fase. Lambang Triyono et.al misalnya, membagi konflik kekerasan Maluku dalam empat fase. Fase pertama adalah konflik yang bermula dari preman yang kemudian berlanjut dengan kerusuhan Ambon. Kerusuhan Ambon ini adalah sebagai fase kedua. Selanjutnya, fase yang ketiga adalah meluasnya konflik Ambon ke pulau-pulau disekitarnya. Sedangkan fase keempat adalah masuknya Laskar Jihad pimpinan Ja'far Umar Thalib ke Maluku'

Sedikit berbeda dengan Lambang Triyono et.al, Nurhasim dan Ratnawati membagi konflik kekerasan ini hanya dalam tiga fase. Fase pertama adalah konflik berdarah yang terjadi pada tanggal 19 Januari 1999 hingga menjelang Pemilu. Fase kedua adalah konflik Pemilihan Umum tahun 1999. Sedangkan fase ketiga adalah masuknya Laskar Jihad ke Maluku pada bulan April 2000. Perbedaan penting antara Lambang Triyono et.al dengan Nurhasim-Ratnawati adalah, Ratnawati-Nurhasim sebelumnya memasukkan fase pematangan konflik dimana hal tersebut tidak ada dalam riset Lambang Triyino et.al ${ }^{2}$.

Berdasar periode dan fase-fase konflik yang terjadi tersebut, dapat diketahui bahwa konflik tersebut tidak terjadi hanya dalam satu peristiwa. Konflik tersebut terjadi berkait erat dan bersambung dengan konflik lain. Dalam pengertian, konflik serta kekerasan yang terjadi di Maluku, pertama terjadi di Ambon baru kemudian ke daerah lain di luar Ambon. Ambon dengan demikian dalam konflik Maluku adalah menjadi pusat pertama konflik dan kekerasan terjadi. Sedang konflik yang terjadi di luar Ambon adalah konflik yang memiliki kaitan erat dengan konflik Ambon meski bukan dalam sifat kausalitas dan liniernya. Dalam hal ini, Ambon merupakan pusat pertama terjadinya konflik, akan tetapi konflik yang terjadi di

${ }^{1}$ Lambang Triyono et.al, Potret Retak Nusantara, (Jakarta: CSPS Books, 2004), h. $108-121$.

${ }^{2}$ Moch. Nurhasim dan Tri Ratnawati, Kapasitas Negara dan Masyarakat Dalam Resolusi Konflik-kekerasan di Ambon, dalam Syafuan Rozi et.al, Kekerasan Komunal; Anatomi dan Resolusi Konflik-kekerasan di Indonesia, (Yogyakarta: P2P-UPI \& Pustaka Pelajar, 2006), h. 119. Untuk melengkapi wawasan, lihat juga laporan Sri Yanuarti (ed), Konflik-kekerasan Maluku Tengah, (Jakarta: IPSK-LIPI, tt.), h. 53. 
luar Ambon (dalam konflik Maluku) tidak selalu berkaitan langsung dengan konflik Ambon.

Konflik yang terjadi di Maluku Utara misalnya adalah konflik yang memiliki kaitan erat dengan konflik yang terjadi di Ambon, akan tetapi bukan dalam sifat kausalitas dan liniernya. Lalu adakah konflik Maluku yang memiliki hubungan kausalitas dengan konflik Ambon? Sebagaimana telah ditulis dan disebut oleh banyak pengamat konflik Maluku, salah satu konflik yang terjadi diluar Ambon yang memiliki kausalitas dengan konflik Ambon adalah konflik yang terjadi di Tual. Salah satu tolok ukur yang digunakan untuk menilai apakah konflik yang terjadi diluar Ambon sebagai kausalitas konflik Ambon atau tidak yaitu didasari oleh perbedaan sebab-sebab mengapa konflik tersebut terjadi.

Konflik di Maluku Utara disebut tidak memiliki kaitan dengan konflik yang meletus di Ambon 19 Januari 1999 adalah karena lebih disebabkan oleh konflik politik, yaitu pertarungan yang menyeret dan melibatkan agama dimana konflik sebenarnya adalah konflik pertarungan mengenai siapa yang berhak dan akan menjadi Gubernur di provinsi yang baru didirikan bulan September $1999^{3}$ tersebut. Sedang Tual disebut sebagai kausalitas konflik Ambon adalah karena konflik yang terjadi di Tual adalah imbas dari konflik dan kekerasan yang terjadi di Benteng Karang, kota Ambon. Benteng Karang adalah salah satu "negeri" di pusat kota Ambon yang penduduknya banyak berasal dari Tual yang disebut orang Kei. Benteng Karang juga, dalam konflik 1999 dianggap sebagai salah negeri Kristen yang berada di antara negeri-negeri muslim.

Pada konflikyang disebabkan oleh lataryang berbeda tersebut, maka upaya penyelesaian konflik yang dilakukan oleh pihak-pihak terkait juga berbeda. Karena itu, konflik Maluku Utara yang lebih disebabkan oleh latar belakang politik, maka upaya penyelesaian yang dilakukan juga diselesaikan melalui jalur politik. Berangkat dari kacamata ini, bagaimana dengan konflik yang memiliki latar belakang yang sama dan memiliki hubungan kausalitas

${ }^{3}$ Gerry van Klinken, Pelaku Baru Identitas Baru: Kekerasan Antar Suku Pada Masa Pasca Suharto di Indonesia, dalam Dewi Fortuna Anwar (ed), Konflik Kekerasan Internal, Tinjauan Sejarah, Ekonomi-Politik dan Kebijakan di Asia Pasifik, (Jakarta: Buku Obor, KITLV-LIPI-LASEMA-CNRS, 2005), h. 102. 
sebagaimana konflik yang terjadi di Ambon dan Tual, apakah juga konflik tersebut diselesaikan dengan cara yang sama? Jika konflik di kedua kota penting di Provinsi Maluku tersebut dianggap sama, maka di antara itu apakah persamaanya. Dan bilamana dianggap berbeda, maka apakah juga perbedaanya. Hal ini mengingat kedua kota penting di Maluku tersebut (Ambon dan Tual), memiliki kaitan sejarah yang tidak jauh berbeda dan saling berkaitan. Pertanyaanpertanyaan ini penting diajukan untuk menjadi pemantik awal mengapa penelitian ini perlu dan penting dilakukan. Namun, dilihat dari cakupannya, pertanyaan pemantik awal ini masih terlalu luas dan umum untuk dijawab, sebab dalam konflik Ambon dan Tual ada banyak instrumen yang terlibat dalam upaya penyelesaian konflik seperti upaya perdamaian yang dilakukan oleh pemerintah, Lembaga Swadaya Masyarakat (LSM), sering disebut dengan Non Goverment Organization (NGO), lembaga-lembaga agama, lembaga-lembaga adat dan sebagainya.

Karena itu, penelitian ini akan memfokuskan diri pada bagaimana model atau bentuk kerjasama antar umat beragama dalam menyelesaikan konflik pada latar konflik yang memiliki hubungan kausalitas di atas. Dengan demikian, dalam hal ini penelitian ini difokuskan pada bagaimana upaya penyelesaian konflik yang dilakukan oleh kelompok-kelompok agama yang ada di Ambon dan Tual dalam bentuk kerjasama antar umat beragama.

\section{B. Menelusuri Akar Konflik Agama di Maluku dan Tual}

Berbagai sumber menuliskan bahwa kerusuhan Ambon dipicu oleh perkelahian antara pemuda asal Sulawesi Selatan bernama Nursalim yang beragama Islam serta bersuku Bugis dengan Yopi Lauhery yang beragama Kristen dari suku Aboru4. Perkelahian tersebut bermula dari Nursalim yang melakukan pemerasan dengan menodongkan sebuah badik $k^{5}$ terhadap Yopi Lauhery sebagai sopir

${ }^{4}$ Nursalim (sumber lain menyebutkan namanya adalah Mursalim) dalam berbagai sumber disebutkan adalah seorang preman dan Yopi Lauhery (Yopi Lauheri memiliki nama babtis Yacop Lauhery) adalah pemuda bersuku Aboru yang berprofesi sebagai supir angkot. Triyono, et.al, Potret Retak ..., h. 109-110.

${ }^{5}$ Badik adalah senjata tradisional dari Makasar berupa seperti pisau kecil yang berpola seperti pedang. Pada masa penjajahan, senjata badik menjadi simbol perlawanan terhadap terhadap penjajahan dan saat ini menjadi sebagai identitas 
hingga berujung pada perkelahian pemuda Nursalim dan Yopi Lauhery.

Dalam perkelahian keduanya itu, Nursalim kalah dari Yopi Lauhery. Nursalim kemudian berlari untuk menyelamatkan diri dari kejaran Yopi Lauhery yang membawa parang ke perkampungan

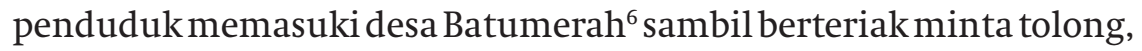
Tolong, orang Kristen itu menyerang saya'. Versi lain menyebutkan, katakata yang digunakan oleh Nursalim adalah 'Tolong, orang Kristen itu hendak membunuh saya'. Menurut peneliti, kata Tolong, orang Kristen itu hendak membunuh saya' sebagaimana tulisan Bambang W Suharto lebih mendekati fakta ucapan yang sebenarnya. Hal ini didasari adanya perbedaan kata dan makna yang cukup mendasar antara 'menyerang dan membunuh'. Kata membunuh memiliki makna dan kesan lebih mendalam daripada kata menyerang dalam pemaknaan konotatif maupun agitasinya. Dalamnya kandungan makna membunuh inilah yang dapat dan telah memicu konflik terbuka yang lebih luas

Teriakan Nursalim dengan segera berubah pada gelombang massa pemuda yang marah dan siap tempur, antara pemuda Muslim di satu pihak dan pemuda Kristen di pihak lain ${ }^{8}$ yang sebenarnya tidak mengetahui alasan perkelahian antara Nursalim dan Yopi

senjata khas tradisional dari Makasar, sama seperti keris di Jawa atau kujang di tanah Priangan.

${ }^{6}$ Batumerah adalah perkampungan yang dihuni oleh mayoritas penduduknya beragama Islam, terletak dipusat kota Ambon. Dilihat dari suku bangsa yang mendiami kampung tersebut, komposisinya cukup merata antara Buton, Bugis, Makasar, suku-suku Ambon dan suku-suku yang lain yang berasal dari luar Maluku seperti Jawa dan Sumba.

${ }^{7}$ Kata-kata Nursalim (Mursalim) ini dikutip dari Triyono, et.al, Potret Retak ....., h. 109-110. Versi lain ucapan Nursalim (Mursalim), seperti hasil penelitian dari penelusuran Bambang W Suharto, kata-kata yang diucapkannya adalah 'Tolong, orang Kristen itu hendak membunuh saya'.

${ }^{8}$ Peristiwa ini terjadi antara pemuda Muslim dan Kristen. Kronologisnya adalah, pada saat pemuda muslim sedang berkumpul menjelang hariraya Idul Fitri, teriakan Nursalim telah membangkitkan emosi massa pemuda Muslim. Pemuda Muslim tersebut berganti mengejar Yacop Luhaery yang kemudian bersembunyi dirumah Silas Noya di kampung Mardika, tidak jauh dari jembatan yang membatasi Mardika dan Batumerah. Sikap pemuda Muslim terhadap Yacob Lauhery disusul bentrokan antara pemuda dari Batumerah (pemuda Muslim) dan Mardika (pemuda Kristen). 
Lauhery. Pemuda Muslim dari kampung Batumerah berada pada pihak Nursalim, sedangkan pemuda Kristen dari kampung Kudamati berada dipihak Yopi Lauhery. Perkelahian antara Nursalim dan Yopi Lauhery menyeret pada perkelahian antara dua kelompok pemuda kampung, antara dua kelompok pemuda berbeda agama dan suku. Perbedaan-perbedaan tersebut setidaknya menjadi dasar utama pelibatan dan kristalisasi kelompok-kelompok dalam dua kutub yang berlawanan hingga pada eskalasi kerusuhan Ambon ke hampir seluruh Kepulauan Maluku.

Tidak diketahui secara pasti kelompok pemuda mana yang telah memulai penyerangan dan pembakaran, sebab kedua belah pihak merasa diserang terlebih dahulu. Kerusuhan dan pembakaran pada kampung-kampung yang terjadi ini sebagai pembenar dan menjadi usaha untuk mempertahankan diri dari ancaman pihak lain. Eksistensi kedua kelompok pemuda merasa saling terancam atas kelompok pemuda yang lain. Kelompok pemuda Muslim merasa terancam akan keberadaan kelompok pemuda Kristen, demikian juga sebaliknya, kelompok pemuda Kristen merasa terancam keberadaannya dari kelompok pemuda Muslim. Rasa saling terancam inilah yang berujung pada konflik kekerasan fisik terbuka dan kerusuhan. Kerusuhan pertama telah menghanguskan beberapa fasilitas umum, perumahan penduduk dan fasilitas keagamaan, hal ini terjadi di kampung Mardika. Beberapa waktu kemudian kerusuhan meluas, disusul dengan pembakaran fasilitas umum dan keagamaan yang berada dipusat-pusat aktifitas di kota Ambon? .

Dengan demikian, kerusuhan Ambon jika dirunut dari awal mengapa kerusuhan terjadi, dipicu pertengkaran antara Nursalim dan Yopi Lauhery. Perlakukan pemuda muslim dari Batumerah yang membantu Nursalim memicu kristalisasi massa Kristen yang bergerak dari daerah Kudamati dan Batugantung ${ }^{10}$ untuk melakukan

${ }^{9}$ Mardika adalah perkampungan yang dihuni oleh mayoritas penduduk memeluk agama Kristen, juga terletak dipusat kota Ambon. Suku bangsa yang mendiami kampung tersebut terutama berasal dari suku-suku lokal Kepulauan Maluku. Kampung Batumerah dan Mardika dipisahkan oleh sungai. Penghubung kedua kampung ini adalah jembatan umum dari sarana tranportasi dari dan ke kota Ambon.

${ }^{10}$ Kudamati dan Batugantung, keduanya adalah perkampungan yang berada tidak jauh dari Mardika, juga didiami oleh masyarakat yang mayoritas penduduknya memeluk agama Kristen. 
pembelaan terhadap Yopy Lauhery, pemuda Kristen merangsek ke pusat kota Ambon. Seketika itu, dari massa pemuda berubah menjadi massa Islam dan Kristen saling berhadapan hingga pecah dalam konflik kekerasan Ambon berdarah tanggal 19 Januari 199911. Konflik inilah yang memicu kerusuhan antara kelompok muslim dan Kristen secara lebih luas di Maluku.

Kerusuhan Maluku bermula dari Ambon dan kemudian menyebar ke penjuru Maluku. Karena itu, para peneliti konflik Maluku membagi penyebaran dan eskalasi konflik-kekerasan tersebut dalam beberapa fase/periode. Namun demikian, secara prinsip perbedaan periodisasi yang digunakan antara peneliti satu dengan yang lain hampir tidak terjadi dalam melihat hubungan antara kerusuhan Ambon dan Tual, bahwa kerusuhan yang terjadi di Tual adalah kelanjutan dari kerusuhan Ambon. Kerusuhan Tual adalah kausalitas konflik di Ambon. Hanya saja, lama masa terjadinya kerusuhan di Ambon dan Tual berbanding terbalik. Kerusuhan Ambon terjadi berkepanjangan, sedangkan di Tual hanya terjadi kurang lebih selama enam bulan terhitung dari bulan April 1999 hingga Oktober 1999 tetapi dengan jumlah korban yang tidak sedikit. ${ }^{12}$

Kerusuhan panjang yang terjadi di Maluku adalah dampak langsung dari konflik kekerasan terbuka 19 Januari 1999. Jika pada bulan Januari-April 1999 kerusuhan hanya terjadi terbatas di pusat kota Ambon, pada akhir periode ini menjadi babak baru konflik-kekerasan Maluku. Akhir masa peralihan periode inilah yang menjadi fase awal penyebaran dan eskalasi konflik ke seluruh Maluku, termasuk ke Tual. Terhitung sejak bulan Mei 1999 konflik kekerasan meluas, terjadi dimulai pada daerah-daerah yang berada

${ }^{11}$ Triyono, et.al, Potret Retak ..., h. 109-110.

${ }^{12}$ Jumlah korban di Tual hingga tahun 1999 adalah 434 orang terdiri dari 187 orang dari kelompok Islam dan 242 dari kelompok Kristen. Jumlah ini merupakan yang terbesar jika dilihat dari periode terjadinya Mei-Oktober 1999. Pada periode yang sama, jumlah korban jiwa akibat konflik-kekerasan di daerah lain di Maluku tidak sebesar yang terjadi di Tual. Bandingkan dengan jumlah korban tewas hingga tahun 2001, Ambon dan Maluku Tengah; 9.753 orang, Maluku Utara; 3.241 orang. Jumlah korban jiwa dalam konflik-kekerasan Tual dianggap lebih besar jika dilihat dari periodisasi terjadinya konflik-kekerasan dibandingkan daerah lain. Lihat dalam Malik Ihsan, Kita Tak Siap Hadapi Perbedaan, Siwa Lima Ambon, Edisi 16, November 2001. 
disekitar kota Ambon dan secara perlahan merambat ke seluruh Maluku. Kerusuhan terutama dalam bentuk penyerangan massal secara sporadis yang diikuti dengan pembakaran rumah-rumah penduduk dan rumah-rumah ibadah. Kerusuhan sporadis yang berada dipinggiran kota Ambon memacu meluasnya konflik terbuka di seluruh Maluku. Konflik sporadis diantaranya terjadi antara desa Ultah (Kristen) dengan Siri Sori (Islam), juga perkelahian penduduk desa di desa Poka yang kemudian meluas ke desa Rumahtiga dan Tihu yang pada periode Januari-Juli tidak terlibat.

Kerusuhan Tual, sebagaimana telah dijelaskan bahwa konflik terbuka yang terjadi di kota ini merupakan kelanjutan dari kerusuhan Ambon. Dalam kerusuhan Maluku, Tual menjadi daerah terparah setelah Ambon. Berikut adalah deskripsi singkat perjalanan kausalitas kerusuhan dari Ambon menuju Tual. Pertama, kerusuhan ini didahului oleh peristiwa di pusat kota Ambon pada 30 Maret 1999. Bermula dari massa muslim se-Kecamatan Leihitu yang ingin membantu saudaranya sesama muslim di masjid AlFatah kota Ambon yang baru saja diserang massa Kristen semalam penuh, massa muslim ini bergerak dari kota Leihitu menuju Ambon. Dalam perjalanan mereka melewati kampung Benteng Karang yang mayoritas penduduknya beragama Kristen dan berasal dari Kepulauan Kei (Tual).

Massa muslim dari Leihitu dan massa Kristen dari Benteng Karang kemudian terlibat dalam konflik terbuka. Dalam bentrok tersebut, massa Kristen dariBentengKarangkalah dan menyelamatkan diri meninggalkan kampung halamannya tersebut. Sebagian besar mereka kembali ke Kepulauan Kei (Tual). Dalam kejadian ini, korban dari kedua belah pihak mencapai 40 orang lebih korban tewas dan 100 orang lebih mengalami luka-luka. Besarnya korban yang jatuh dan terusirnya warga Kristen Benteng Karang dalam konflik terbuka ini menjadi salah satu faktor penting pemicu kerusuhan terbuka di Tual ${ }^{13}$. Kekalahan dalam perang terbuka massa Kristen di Benteng Karang oleh massa muslim dianggap sebagai pukulan telak baik dilihat dari kekuatan massa maupun psikologis karena Benteng Karang adalah basis kekuatan Kristen.

${ }^{13}$ Rustam Kastor, Selamatkan Maluku Dari Ancaman idologi Separatis Republik Maluku Selatan, cet ke-1, (Jakarta: Komite Penyelamat Maluku (KPM), 2004), h. 39. 
Pasca peristiwa Benteng Karang 30 Maret 1999, Fiet Farfar ${ }^{14}$ bersama beberapa orang melakukan penghasutan kepada warga Kristen di Tual. Hal ini ia lakukan pada tanggal 1 April 1999. Farfar mengajak umat Kristen di Tual ${ }^{15}$ untuk melakukan penyerangan terhadap penduduk muslim sebagai cara untuk mempertahankan diri. Apa yang dilakukan oleh Farfar ini menjadi pemantik kerusuhan yang terjadi di Tual. Sebagaimana telah disebut sebelumnya, jumlah pemeluk Kristen yang hanya $21.82 \%$ dari keseluruhan penduduk Tual menimbulkan kekhawatiran tersendiri bagi kelompok Kristen di Tual. Karena itu, cara yang kemudian di tempuh oleh kelompok Kristen adalah menyerang dahulu "negeri-negeri" Islam.

Fiet Farfar dan massa Kristen di Tual terprovokasi oleh selebaran hasil pemalsuan surat keputusan Majelis Ulama Indonesia Maluku yang harusnya bertanggal 26 Januari 1999. Surat keputusan tersebut dipalsukan TPG sehingga bertanggal 6 Januari 1999, padahal surat keputusan itu berisikan tentang seruan pada umat Islam untuk melakukan pembelaan diri pada hak dan kewajiban sebagai umat Islam. Pemalsuan tanggal tersebut berimplikasi pada, jika kerusuhan Ambon terjadi pada 19 Januari 1999, maka tanggal 6 Januari 1999 berarti terjadi sebelum peristiwa Ambon berdarah. Hal ini memicu kemarahan umat Kristiani yang menuduh umat Islam telah mempersiapkan penyerangan secara matang dan tersistematis ${ }^{16}$.

Pasca peristiwa 1 April 1999, kerusuhan terbuka dan bentrok fisik tidak dapat dihindari di Tual. Massa Katolik yang tidak memiliki kaitan sama sekali pada konflik-kekerasan Tual pun terprovokasi oleh surat palsu tersebut dan kemudian juga menyerang "negerinegeri” yang mayoritas penduduknya beragama Islam karena takut diserang terlebih dahulu oleh massa muslim. Penyerangan yang dilakukan oleh massa Kristen dan Katolik ini memicu serangan balasan massa muslim terhadap “negeri-negeri” Kristen dan Katolik.

${ }^{14}$ Fiet Farfar adalah Sekretaris Daerah (Sekda) Maluku Tenggara.

${ }^{15}$ Tual yang dimaksudkan adalah Kepulauan Kei. Tual pada masa ini masih menjadi ibukota Maluku Tenggara sebelum akhirnya dimekarkan menjadi daerah otonom Kota Tual pada tahun 2007.

${ }^{16}$ TPG adalah kependekan dari Tim Pengacara Gereja. Selanjutnya baca Ulasan pemalsuan himbauan pada umat Islam untuk membela diri yang termaktub dalam Surat Keputusan Majelis Ulama Indonesia Maluku. 
Dan kemudian diseluruh Tual, massa Islam, Kristen dan Katolik saling menyerang ${ }^{17}$.

Lambang Triyono et.al membagi eskalasi kerusuhan Maluku dalam beberapa fase penting, pertama bermula dari preman, kedua kerusuhan Ambon jilid II, ketiga kerusuhan dari Geaga Silo ke pulaupulau dan keempat adalah masuknya Laskar Jihad dan perkembangan konflik. ${ }^{18}$ Pembagian fase yang hampir sama dikemukan oleh Nurhasim dan Tri Ratnawati, hanya saja keduanya membagi dalam 3 fase, mengutip Baku Bae, periode pertama dimulai pada 19Januari 1999 atau Idul Fitri berdarah, kedua periode pasca Pemilu 1999 dan ketiga dengan mulai masuknya Laskar Jihad ke Ambon pada April 2000. Meski keduanya membagi dalam tiga fase, Nurhasim dan Ratnawati mendeskripsikan telah terjadi adanya bentuk 'pematangan' konflik pada bulan Desember 1998. Pematangan konflik yang dimaksud adalah perang kecil antara kelompok pemuda muslim dan Kristen di desa Air Bak dan desa Wailette, juga terjadi di Pulau Dobo ${ }^{19}$.

Bambang W. Suharto menambahkan pematangan konflik tersebut secara lengkap dengan memulainya dari; pertama, peristiwa kerusuhan Ketapang 21 November 1998 antara preman Ambon (beragama Kristen) dengan penduduk Ketapang (beragama Islam) yang berlanjut pada pemulangan preman Ambon ke Maluku. Kedua, perkelahian antara dua warga beda agama di dusun Air Bak pada 18 September 1998. Ketiga, peristiwa pemukulan polisi (Praka Sahara, beragama Islam) terhadap petugas keamanan kampung (beragama Kristen) di Wailette pada 13 Desember 1998. Keempat, Isu penampakan Yesus di Gudang Arang pada 14 Januari 1999. Isu ini menjadi mobilisasi massa Kristen Maluku menuju Ambon. Kelima, demonstrasi mahasiswa di Polda dan Korem Maluku di mana dalam demonstrasi itu diteriakkan yel yel 'mena muria' sebagai salam dukungan terhadap RMS. Keenam, Kerusuhan warga beda agama di Dobo, ibukota kecamatan Kepulauan Aru pada 15-17 Januari 1999. Ketujuh, memanasnya suhu politik menjelang pelaksanaan

${ }^{17}$ Dalam hal ini massa Kristen dan Katholik meski tidak memiliki kaitan, kedua massa dari dua agama ini menyerang negeri-negeri Islam. Makna lainnya, konflik-kekerasan ini bukan konflik-kekerasan segitiga antara Islam, Kristen dan Katholik, tetapi Islam disatu pihak dan Kristen-Katholik dipihak lain.

${ }^{18}$ Triyono et.al (ed), Potret Retak..., h. 108-121.

${ }^{19}$ Nurhasim dan Ratnawati, Kapasitas Negara ..., h. 119. 
Pemilu 1999 dengan beredarnya banyak isu-isu SARA untuk meraih dukungan politik. Peristiwa-peristiwa tersebut telah menjadi pematangan konflik karena menjadi permulaan kristalisasi massa berbeda Agama, terutama Islam dan Kristen di Maluku.

Kerusuhan yang dipicu peristiwa pemalakan tersebut, jika sebelumnya menggunakan simbolisasi agama Islam dan Kristen, dan menyeret keduanya pada kekerasan berdarah, pada hari yang sama kerusuhan tersebut meluas menyeret faktor kesukuan (etnisitas). Suku-suku tertentu diidentifikasikan pada identitas agama-agama. Penolakan terhadap keberadaan suku Bugis, Buton dan Makasar (BBM) merupakan penolakan massa Kristen terhadap keberadaan massa muslim di Maluku. Istilah BBM jika sebelumnya hanya menjadi wacana pinggiran berubah menjadi wacana politik utama di Ambon. Istilah ini menjadi sangat familiar didengar oleh masyarakat umum. Sebaliknya, isu BBM dibalas oleh massa muslim dengan menyuarakan penolakannya terhadap Republik Maluku Selatan (RMS). Oleh massa muslim, RMS diidentikkan dengan massa Kristen. Selanjutnya, peristiwa ini kemudian mengkristal pada opiniopini, massa muslim yang pro terhadap NKRI dan massa Kristen yang pro terhadap RMS atau anti NKRI. Kristalisasi opini dan isu ini kemudian menyeret militer terlibat, pada masa itu aparat militer adalah ABRI dimana TNI dan Polisi masih menjadi satu institusi.

\section{Penyelesaian dan Penghambat Kerjasama Perdamaian Antar Umat Beragama di Maluku dan Tual}

Konflik Maluku baik di wilayah Ambon maupun di Tual dapat dibedakan dalam dua konteks, yaitu: konteks lokal dan konteks nasional. Keduanya merupakan faktor-faktor pemicu terjadinya konflik komunal di wilayah tersebut. Konteks lokal merupakan potensi konflik yang dimiliki suatu daerah berdasarkan tinjauan sosio-geografis dan sosio-historis yang unik. Konteks lokal, telah berproses dalam jangka-waktu yang cukup lama, lebih dari masa satu generasi dan ada yang telah beroperasi lebih dari seratus tahun. Sedangkan konteks nasional atau dapat pula disebut sebagai konteks eksternal, adalah merupakan faktor ikutan, baik berupa kebijakan pemerintah pusat yang menimbulkan ketidakmerataan dan ketidakadilan kesempatan, maupun kekerasan struktural 
terhadap kelompok masyarakat tertentu, atau keikutsertaan pihak luar dalam konflik baik sebagai aktor konflik, maupun kelompok yang berkepentingan terhadap konflik, seperti golongan pedagang senjata maupun provokator. Dari dua konteks konflik tersebut di atas, kita dapat memetakan faktor-faktor pemicu konflik komunal di Maluku secara umum kedalam dua konteks tersebut. Dilihat dari konteks lokal, faktor-faktor pemicu konflik antara lain:

Pertama, pola pemukiman yang tersegregasi menurut suku dan agama. Di Maluku, sejak dari pulau Morotai dan Halmahera di MalukuUtara sampai dengan pulau-pulau Kei dan Tanimbardi Maluku Tenggara, masyarakat bertempat tinggal mengelompok menurut suku dan agama. Satu desa eksklusif suku dan agama tertentu, bahkan dalam satu kecamatan di sana bisa ditemukan kecamatan eksklusif satu suku atau agama tertentu dengan beberapa kantong perkampungan dari suku dan agama yang berbeda. Penarikan batas yang jelas ini, di satu pihak, kedalam sesama warga berfungsi sebagai penegasan rasa ke-kita-an (sense of community) sekaligus untuk menjamin rasa aman (physical safety) dan lahan untuk mewadahi kegiatan bersama dalam mengusahakan kesejahteraan, di lain pihak, merupakan pengakuan akan eksistensi sub suku lain yang juga dihormati haknya untuk hidup berdampingan secara damai.

Kedua, persaingan sengit antar lembaga-lembaga agama lokal seperti dalam upaya memperbanyak pengikut maupun dalam memperluas teritori agama. Persaingan ini terjadi, misalnya antara Gereja Protestan Maluku dengan Majelis Ulama Indonesia Maluku maupun dengan organisasi-organisasi Islam seperti NU dan Muhammadiyah. Juga di Halmahera, antara Gereja Masehi Injili Halmahera (GMIH) dengan lembaga-lembaga Islam setempat. Persaingan ini telah berlangsung lebih dari 157 tahun sejak cikalbakal GMIH didirikan pertama kali di Halmahera Utara.

Ketiga, berkembangnya gerakan-gerakan separatis di Maluku seperti Republik Maluku Selatan (RMS) semenjak masa-masa awal kemerdekaan, merupakan ancaman keamanan tersendiri bagi Maluku. Hal inilah yang senantiasa menjadikan Maluku sebagai objek operasi militer. RMS tentunya sangat berkepentingan terhadap kekacauan di Maluku, dengan demikian usaha-usaha merongrong kedaulatan RI di tanah Maluku berhasil dilakukan. 
Dilihat dari konteks nasional, maka faktor-faktor pemicu konflik antara lain, semakin dominannya posisi para politisi Islam berbasis perkotaan di panggung perpolitikan nasional, khususnya Golkar di era 1990-an terutama setalah ICMI terbentuk dan para 'Perwira Hijau' dalam ABRI memegang kendali komando. Ketika DPR RI hasil Pemilu 1992 bersidang jelas sekali bagaimana lembaga ini di dominasi oleh Golkar. Dalam kamp militer juga teramati kecenderungan yang sama. Para perwira 'hijau' seperti Jend. (pur) Faisal Tanjung menjabat sebagai Panglima ABRI sedangkan Jend. (Pur) Hartono menjadi Kepala Staf Angkatan Darat serta Letjen (Pur) Prabowo Subianto menjabat Komandan Jenderal Kopassus dan kemudian Panglima Kostrad. Sedangkan para perwira Merahputih yang dianggap menjadi pengikut Jend. (Pur) Benny Murdani disingkirkan.

Seiring dengan perkembangan yang disebut pertama ini, para politisi IRAMASUKA yang didominir oleh mereka dari suku Bugis juga semakin kuat posisi mereka mengitari Habibie sebagai Ketua Harian Dewan Pembina Golkar. Kedua perkembangan di panggung nasional ini memberi angin dan peluang kepada para politisi Islam berbasis perkotaan khususnya mereka yang berasal dari suku Bugis, berperan di Sulawesi secara keseluruhan. Setiap perkembangan politik di Indonesia Timur dikendalikan oleh lingkaran-dalam dari para politisi Golkar asal Bugis. Dominannya kelompok politisi Nasional-Islam-modernis berbabasis perkotaan ini dimanfaatkan oleh para elit lokal dari kelompok yang sama. Para politisi berbasis ICMI, HMI ataupun Muhammadiyah merebut momentum ini untuk menancapkan dominasi mereka dalam arena politik lokal. Hal ini justru mengancam eksistensi para pemimpin lokal berbasis gereja yang telah menguasai birokrasi pemerintahan lokal semenjak masa penjajahan.

Masuknya migran ke wilayah Maluku. Para migran ini sangat beragam dan berasal hampir dari seluruh Indonesia, sejak dari suku Minang, Sunda, Jawa, Bugis, Buton, Makasar, Gorontalo sampai dengan dari kepulauan Sangir-Talaud di Sulawesi Utara. Kelompok migran yang disebut empat yang pertama pada umumnya beragama Islam mendatangi kota-kota di Maluku dan Maluku Utara seperti Tobelo, Ternate, Masohi, Ambon dan Tual. Hanya suku Sangir-Talaud 
yang bertransmigrasi ke kecamatan Galela, Maluku Utara yang beragama Kristen. Di Galela mereka membentuk permukiman yang terpisah di dua desa, yaitu desa Makete dan desa Pune Pantai. Pada umumnya pendatang beragama Islam dari keempat suku tersebut tidak menimbulkan gejolak pada saat pada saat mereka bermukim di Maluku Utara yang $87 \%$ penduduknya beragama Islam. Lain halnya dengan suku Sangir-Talaud yang berdiam di kecamatan Galela yang mayoritas beragama Islam, pernah mengalami gejolak konflik lokal, yaitu pada tahun 1955 ketika terjadi pemberontakan DI-TII dan pada saat G 30 S PKI terjadi konflik terselubung bernuansa agama dan suku antara pendatang Kristen ini dengan muslim lokal. Kedatangan suku-suku Bugis, Buton dan Makasar ke Kotamadya Ambon juga mempengaruhi tatanan masyarakat lokal. Sebelum kedatangan migran BBM ini proporsi umat Kristen dalam Kotamadya Ambon sedikit lebih banyak dari proporsi umat Islam. Derasnya arus migran BBM yang mulai berlangsung di pertengahan kedua dekade tahun 1980an dan awal dekade 1990an telah merubah kesimbangan itu, sehingga proporsi umat Islam menjadi sedikit lebih besar dari proporsi umat Kristen dalam Kotamadya Ambon. Di tingkat akarrumput, penduduk asli Ambon baik yang Islam maupun yang Kristen mulai terdesak dalam memperebutkan lahan pemukiman dalam kota Ambon. Persaingan juga berlangsung di pasar-pasar tradisional yang semakin dikuasai oleh para pedagang kecil dan menegah dari Sulawesi Selatan. Akibat ikutan dari berdatangannya pendatang ke wilayah-wilayah konflik ini adalah semakin menyempitnya ruang kehidupan penduduk asli.

Terjadinya penghancuran sistematik lembaga-lembaga adat tradisional. Hal ini terutama masif terjadi di kota Ambon. Penghancuran secara sitematik lembaga-lembaga ini dilakukan oleh dua pihak. Pertama, pihak pemerintah Orde Baru lewat penerapan UU No. 5 tahun 1975 dan UU No. 5 tahun 1979 yang menyeragamkan seluruh tatanan desa di seluruh Indonesia dengan bermodelkan tatanan desa di Jawa. Tatanan sosial dipangkas kaitannya dengan tatanan pemerintahan desa. Kepala Desa lebih bergantung ke atas sebagai pegawai negeri-yang dalam banyak kasus tidak mengenal budaya setempat-daripada ke bawah ke masyarakat desa. Pihak kedua yang menghancurkan secara sistematik tatanan tradisonal adalah 
pihak lembaga-lembaga agama, baik dari pihak Kristen maupun pihak Islam. Gereja Kristen Maluku beranggapan bahwa lembaga Pela di Maluku Tengah dapat menjadi penghambat proses Kristenisasi. Karena itu, perlu digembosi. Demikian juga Muhammadiyah di Maluku dan Maluku Utara bersikap tidak bersahabat dengan berbagai tradisi lokal karena dianggap merupakan wujud-wujud takhyul, bid'ah dan khurafat yang tidak Islami.

Dilihat dari faktor pemicu konflik tersebut di atas, baik faktor internal dalam konteks lokal, maupun faktor ekternal dalam konteks nasional, dapat disimpulkan bahwa konflik Maluku yang dimulai pada kerusuhan Januari 1999 tersebut, memiliki dimensi konflik yang sangat kompleks. Sehingga upaya penyelesaiannya pun perlu dilakukan secara menyeluruh. Upaya resolusi konflik yang dilakukan pemerintah atau para stakeholder perdamaian, tentunya tidak hanya terbatas pada upaya-upaya penghentian kekerasan dan peleraian semata, namun juga rekonstruksi sosial ekonomi dan penguatan identitas lokal sebagai faktor pendamai jangka penjang perlu segera dilakukan. Hal ini tentunya dimaksudkan untuk menghindari masih berkembangnya konflik laten yang akan memicu konflik komunal lagi dimasa yang akan datang. Dengan demikian, usaha berkesinambungan dan kerjasama seluruh lapisan masyarakat dan pemerintah diperlukan.

Dalam bagian ini penulis akan memetakan kembali faktor-faktor pendorong dan penghambat perdamaian pasca upaya peleraian dan penghentian kekerasan di Tual dan Ambon. Perbandingan Tual dan Ambon dimaksudkan untuk mendapatkan pola-pola resolusi yang berhasil diterapkan di suatu wilayah yang nanti akan menjadi masukan kebijakan perdamaian di wilayah Maluku lainnya. Hal ini Diperlukan sebagai bahan revisi dan refleksi bagi para stakeholder konflik untuk upayaupaya perdamaian berkesinambungan, sehingga konflik serupa diharapkan tidak terjadi lagi di tanah Maluku. Dalam penelitian ini penulis membandingkan perdamaian di Ambon dan Tual sebagai representasi upaya perdamaian di Maluku pada umumnya.

\section{Penunjang Keberhasilan Kerjasama Perdamaian di Ambon}

Berdasarkan pengamatan penulis, terdapat beberapa faktor 
pendukung perdamaian semenjak perjanjian di Ambon, yaitu antara lain sebagai berikut:

a. Kesadaran Masyarakat Ambon Menghentikan Konflik. Konflik Ambon berlangsung selama kurang lebih empat tahun. Dalam masa empat tahun tersebut korban jiwa dan harta benda tidak terhitung. Hal ini menimbulkan pemikiran dan kesadaran masyarakat akan dampak buruk yang ditimbulkan selama konflik. Kejenuhan akan konflik yang berkepanjangan ini ternyata timbul disegala aspek masyarakat, baik pada tingkatan elit masing-masing pihak yang bertikai, maupun masyarakat tingkat bawah yang terutama merasakan dampak konflik paling parah. Inilah yang merupakan faktor pendorong utama perdamaian di kota Ambon pasca perjanjian Malino pada tahun 2002. Dengan timbulnya kesadaran masyarakat untuk mengakhiri konflik tersebut, maka integrasi sosial manuju pada cita-cita perdamaian menjadi semakin mudah dicapai. Hal ini diperkuat oleh pernyataan Menko Kesra HM Jusuf Kalla pada tanggal 10 Februari 2002. JK menyatakan konflik Ambon yang sudah berlangsung tiga tahun harus berhenti. Ia mengatakan tidak ada pilihan, perselisihan mesti usai dan Ambon harus damai. Jika tidak damai, masyarakat Maluku, khususnya Ambon, akan menjadi paria, miskin dan terbelakang dari aspek apapun. $^{20}$

b. Kerjasama Berbagai Pihak dalam Mewujudkan Perdamaian. Perdamaian di Ambon ternyata tidak hanya diwujudkan oleh pemerintah dan kalangan elit agama saja, namun kerjasama dan kesolidan berbagai pihak baik dari kalangan organisasi kemasyarakatan lokal maupun luar Ambon, kaum akademisi dan agen-agen perdamaian individu yang mengerahkan segala cara dan pendekatannya masing-masing. Kalangan LSM seperti gerakan Baku Bae, menggunakan cara-cara kultural untuk mempersatukan kembali masyarakat beda agama yang telah terlanjur tersegregasi dalam dua kelompok yang berbeda. Lembaga Antar Iman di Ambon juga senantiasa mengadakan

${ }^{20}$ John Pieris, Tragedi Maluku, Sebuah Krisis Peradaban (Analisis Kritis Aspek Politik, Ekonomi, Sosial-Budaya, dan Keamanan), (Jakarta: Yayasan Obor Indonesia, 2004), h. 300 . 
kegiatan-kegiatan baik lokakarya dan memberikan pendidikan perdamaian terhadap masyarakat. Sedangkan lembaga-lembaga akademis seperti halnya pusat studi keamanan dan resolusi konflik dan beberapa peneliti juga memberikan sumbangsih dan penerangan kepada masyarakat luas tentang situasi di Ambon, kalangan akademisi juga memfasilitasi pertemuan tokohtokoh masyarakat dan mengupayakan rekonsiliasi lanjutan pasca Malino. Di samping itu individu baik dan para perantau dari Ambon yang senantiasa memberikan bantuan moriil maupun materiil turut juga membantu jalannya perdamaian di Ambon.

c. Peran Militer dan Aparat dalam Menjaga Stabilitas Pasca Konflik. Meskipun pasca penetapan Darurat militer oleh presiden Abdurrahman Wakhid, keterlibatan militer di Ambon dikecam, ditambah lagi dengan hilangnya kepercayaan masyarakat akan netralitas militer dan aparat, namun harus diakui bahwa unsur-unsur militer telah memberikan sumbangsih besar pada penciptaan rasa aman dan terjaminnya stabilitas di Ambon. Upaya-upaya penghentian konflik terbuka dan tindakantindakan kekerasan yang mendukung berhasilnya perundingan, ternyata berhasil dilakukan oleh aparat dan militer terutama pada masa-masa pasca perjanjian Malino I dan II.

\section{E. Penghambat Keberhasilan Kerjasama Perdamaian di Ambon} Ambon:

Berikut adalah Faktor-faktor penghambat perdamaian di

a. Heterogenitas dan Segregasi Sosial Pasca Konflik. Konflik terbuka berskala massal dengan penggunaan kekerasan bukanlah peristiwa yang bisa serta merta terjadi. Mesti ada tahapan atau fase-fase yang dilalui. Konflik seperti itu hanya bisa terjadi kalau ada prakondisi yang memungkinkan dan mencukupi bagi terjadinya konflik terbuka. Prakondisi demikian umumnya merupakan hasil dari sebuah proses ketidakpuasan yang terakumulasi akibat perubahan-perubahan dalam jangka waktu yang lama. Perang antar etnis dan pemeluk agama yang disinyalir juga diboncengi oleh kelompok kepentingan, adalah luapan frustasi akibat benturan berbagai nilai budaya, represi 
politik, dan sosial ekonomi. ${ }^{21}$ Hal ini juga diperparah rekayasa dan penyeragaman sosial budaya yang gencar dilakukan pemerintah sejak masa Orde Lama hingga Orde Baru yang kemudian menghancurkan tatanan tradisional yang telah berkembang sejak masa nenek moyang bangsa Ambon. Dengan demikian konflik justru memperparah segregasi sosial dalam masyarakat dan jurang pemisah antara kelompok Islam dan kristen. Pengkotak-kotakkan masyarakat ini pun terjadi baik secara alamiah maupun melalui upaya pemerintah untuk meminimalisir tindak kekerasan. Meskipun tujuan pemisahan ini baik untuk masa-masa peleraian dan dalam waktu dekat, akan tetapi dalam masa yang cukup lama, segregasi sosial masyarakat justru semakin memapankan konstruk identitas yang berbeda antar kelompok masyarakat yang berbeda, sehingga integrasi sosial dan upaya-upaya pembauran gagal dilakukan. Segregasi masyarakat Ambon yang terpisah berdasarkan agama ini juga diperparah dengan hadirnya golongan-golongan pendatang seperti dari Sulawesi, Jawa, Sumatra dan beberapa daerah Indonesia lainnya semenjak era Orde Baru, membawa persoalan tersendiri bagi kota Ambon. Golongan-golongan pendatang ini berhasil memegang kesempatan ekonomi, pendidikan, sosial bahkan kedudukan politik dan menyingkirkan kesempatan panduduk asli. Hal ini menimbulkan persoalan ketimpangan ekonomi dan semakin kompleksnya persoalan sosial yang dihadapi kota Ambon pasca konflik. Kelompok masyarakat ini pula jauh dari tradisi dan kebudayaan masyarakat asli seperti halnya pela gandong, salam sarani, aini ain, dan konstruksi identitas lokal lainnya. Hal ini mempersulit upaya rekonsiliasi melalui jalan-jalan kultural. Sementara pendatang ini rata-rata telah bermukin lama di Ambon, sehingga sumber kehidupan mereka bergantung pula dari kegiatan ekonomi dan sosial di Ambon.

b. Primordialisme dan Politisasi Agama. Konflik yang berkepanjangan tidak hanya menimbulkan kerusakan fisik dan korban jiwa,

${ }^{21}$ Ivan Alwi Alhadar Dalam Binny Buchori, George Yunus Adicondro dkk, Ketika Semerbak Cengkih Tergusur Asap Mesiu, Tragedi Kemanusiaan Maluku Dibalik Konspirasi Militer, Kapitalis Birokrat dan Kepentingan Elit Politik, (Jakarta : Tapak Ambon, 2001), h. 24. 
namun juga trauma psikologis, terutama bagi masyarakat yang kehilangan tempat tinggal dan anggota keluarganya pada masa konflik. Rehabilitasi mental masyarakat ini memerlukan waktu yang tidak singkat. Sementara perhatian pemerintah masih terpusat pada rehabilitasi fisik. Kondisi ini menjadikan stereotipe, trauma, dan kecurigaan dikalangan masyarakat. Ditambah pula dengan kepercayaan masyarakat terhadap proses perdamaian dan rekonsiliasi yang masih minim, sehingga kerentanan terhadap tindakan kekerasan baru masih selalu mengancam.

c. Kegagalan Pemerintah dalam Upaya Rekonstruksi Sosial-Ekonomi Pasca Konflik. Pasca konflik Ambon dan Tual, pemerintah telah memprakarsai perdamaian antara kedua komunitas melalui perjanjian Malino sampai pada perjanjian Baku-Bae Satu dan Dua, serta perjanjian lain baik yang dilaksanakan di dalam daerah Maluku ataupun dilaksanakan di luar daerah Maluku seperti yang telah diprakarsai oleh Sultan Jogya mengundang para Latu Pati untuk duduk bersama, bertukar pikiran dan pandangan untuk menemukan titik temu antara pihak-pihak yang bertikai dan semuanya mengalami kemajuan yang berarti bagi perdamaian di Maluku. Selain upaya diatas pemerintahpun memperbaiki sarana-sarana sosial dan peribadatan seperti Masjid dan Gereja melalui dana Inpres 6 yang didalamnya digunakan untuk hal-hal ibadah dan sosial. Pemerintahpun memperbaiki sentra-sentra perdagangan tradisional atau pasar tradisional juga perbaikan jalan-jalan umum yang rusak akibat konflik. Selain bantuan pemerintah untuk memperbaiki sarana dan prasarana umum, pemerintah juga membantu pengungsi yang terkena imbas konflik dengan memberikan bantuan berupa biaya renovasi rumah pengungsi dan merelokasi pengungsi dengan pembangunan perumahan pengungsi pada lokasi-lokasi yang terbakar akibat kerusuhan. Bantuan yang dijalankan pemerintah sejak tahun 2004 sampai dengan tahun 2007 itu cukup memberikan stimulus bagi pengungsi yang di dalamnya berupa uang perbaikan rumah, uang pemulangan pengungsi dan uang lauk-pauk yang mencukupi kebutuhan pengungsi untuk kembali dan hidup di tempat asal selama beberapa bulan. 
Di bidang pendidikan pemerintah membangun kembali sekolahsekolah yang rusak mulai dari jenjang pendidikan dasar (SD) sampai tingkatan SMA dan perguruan tinggi seperti Universitas Pattimura yang mana adalah satu-satunya Universitas Negeri yang ada di Maluku dan telah menjadi kebanggaan masyarakat Maluku. Pemerintah juga memperbaiki sarana dan prasarana lainnya seperti kantor-kantor pemerintahan dan kantor-kantor swasta, asrama polisi di Tantui, rumah sakit, dan tentunya kantor Gubernur Maluku sebagai pusat kontrol pemerintahan di Maluku. Jika ditilik secara jangka pendek, upaya-upaya yang dilakukan pemerintah telah banyak menyentuh perbaikan kehidupan sosial ekonomi masyarakat pasca konflik, akan tetapi berdasarkan pengamatan penulis, dibeberapa sudut kota Ambon pun masih terdapat kantong-kantong pengungsian yang luput dari perhatian, mereka ini seolah-olah terkatung-katung di barak-barak pengungsian tanpa kejelasan nasib dan masa depan, padahal mereka merupakan potensi masalah sosial yang dapat kembali memicu terjadinya konflik-konflik baru. Oleh karenanya upaya-upaya rehabilitasi pemerintah seyogyanya tidak hanya ditekankan pada rehabilitasi fisik semata, namun juga rehabilitasi sosial masyarakat. Masalah-masalah seperti krisis pemerintahan, keamanan, kesenjangan sosial ekonomi, kesenjangan kelas sosial ekonomi, belum tersentuh oleh berbagai kebijakan dan respon pembangunan dan perdamaian selama ini.

d. Perdamaian Tidak Berlangsung Integratif. Perdamaian di Ambon seperti halnya prakarsa perjanjian Malino, kebanyakan dilakukan dengan model top-down yang sifatnya struktural dan formal, dan hanya menyentuh sebagian dari stakeholder konflik terutama dari kalangan elit. Sementara elit masyarakat yang terlibat dalam perjanjian perdamaian belum dapat menjamin dan memahami perdamaian kepada masyarakat luas dan masyarakat lapisan bawah yang justru kebanyakan terlibat secara langsung dalam konflik. Dalam kasus Ambon, agen-agen perdamaian hanya melibatkan tokoh-tokoh dari kelompok masyarakat yang bertikai, tanpa melibatkan kelompok lain yang meskipun tidak terlibat konflik, namun mereka juga merasakan dampak konflik tersebut. Misalnya perjanjian di 
beberapa daerah hanya melibatkan tokoh-tokoh agama Islam dan kristen, padahal di Ambon terdapat tokoh-tokoh agama lain seperti Katolik, Hindu Budha, yang juga merasakan imbas konflik.

\section{F. Penunjang Keberhasilan Kerjasama Perdamaian di Tual}

Pasca kerusuhan di Tual, potensi kearifan lokal seperti hukum adat lar vul ngabal, dan pemimpin tradisional seperti halnya rajaraja dan saniri negeri masih memegang peranan yang cukup kuat di beberapa tempat sebagai media pemersatu masya-rakat. Hal inilah yang menjadikan kerusuhan di Tual dapat segera di tanggulangi. Berbeda dengan di Ambon, di Tual meskipun agama memegang nilainilai primer dalam masyarakat, namun adat istiadat dan perasaan "sekandungan", dirasakan masih kuat mengakar dalam tradisi kehidupan masyarakat Tual. Sehingga, jika potensi lokal dimanfaatkan sebagai katalisator perdamaian dan integrasi masyarakat dapat berfungsi efektif.

Dengan dibukanya ruang partisipasi semua kalangan, diharapkan semua elemen dapat mengidentifikasi diri sebagai bagian dari proyek perdamaian. Sehingga beban berat akan bisa ditopang bersama. Meskipun tidak seluruh masyarakat merasa dilibatkan dalam konflik, namun lapisan masyarakat lain yang juga mengalami imbas konflik, perlu di dudukkan bersama dalam forum perdamaian. Hal ini dimaksudkan untuk melibatkan semua lapisan dalam upaya rekonsiliasi, dan mempertegas kembali identitas sebagai masyarakat yang satu.

Dalam kasus Tual, inisiatif perdamaian justru muncul dari pihak ketiga yang tidak mengalami konflik, dalam hal ini golongan perantauan asal Maluku Tenggara di Jakarta, yang dengan aktif memfasilitasi upaya-upaya perdamaian di Tual.

Ketika masyarakat terbelah menjadi dua antara kelompok Islam dan Kristen, tokoh-tokoh perantauan dari Tual segera berinisiatif untuk membuka dialog. Pada waktu kerusuhan di Ambon meletus Januari 1999, mereka mulai menjalin komunikasi di Jakarta dan kemudian membentuk Keluarga Besar Masyarakat Maluku Tenggara (KBMMT). "Sejak dahulu kami terikat dengan ain ni ain, kita adalah satu. Sebelum agama datang, kami satu keluarga, 
baru kemudian ada yang beragama Islam, Kristen, Katolik, Budha dan sebagainya“ kata Taher yang menjadi ketua KBMMT. ${ }^{22}$ Dengan menjaring aspirasi dan koordinasi organisatoris seperti dibentuk di atas, setidaknya ada saluran-saluran komunikasi yang bisa dijadikan mediasi, memahami posisi-posisi melalui dialog untuk mengurangi kebencian-kebencian yang sebenarnya tidak lebih sebagai manifestasi kesalahpahaman satu sama lain.

Semua pihak yang mendukung perdamaianpun menjadi bagian integral yang perlu memperoleh proporsi dalam proses ini. Dalam upaya mewujudkan upaya perdamaian di Maluku teng-gara, peran serta outsider(perantauan), ternyata menjadi faktor pendorong terwujudnya perdamaian. Meskipun, perantauan berada diluar barisan konflik, solidaritas dan empati mereka telah memperbesar ruang harapan akan perdamaian.

Suasana bersahaja para perantau yang datang ke desanya rupanya menimbulkan sebuah keajaiban. Masyarakat yang menaruh hormat terhadap niat baik para perantau itu kemudian berdatangan ke posko, saling mengungkapkan keluhannya, bahkan dalam berbagai kejadian bertangis-tangisan dan berangkulan di tempat tersebut. Setelah komunikasi dibangun, dibuatlah kesepakatan kesepakatan tertulis dari tokoh-tokoh adat dan kepala desa berisi kesediaan mengakhiri kerusuhan, kemauan menjalin kerukunan, dan keinginan untuk membangun kembali sarana dan prasarana yang rusak..$^{23}$ Sinergisitas dari semua pihak kreatif pendorong perdamaian itu setahap demi setahap mentransformasi dari keadaan keotik menjadi kondisi yang lebih damai. Embrio yang tercipta ini kemudian bisa dijadikan acuan dalam menularkan proses perdamaian ke ruang yang lebih besar, baik wilayah, maupun ruang sosial yang lebih luas.

\section{G. Penutup}

Mengakhiri diskusi resolusi konflik komunal di Ambon dan Tual khususnya dan secara umum di Indonesia dalam perspektif multikultural, dapat dikemukakan bahwa sebenarnya konflik yang sering terjadi di wilayah timur Indonesia akhir-akhir ini sering

\footnotetext{
${ }^{22}$ Kisah Perdamaian dari Tual, http://www.kompas.com ${ }^{23}$ Ibid.
} 
mengandung muatan yang kompleks. Muatan politis agaknya paling dominan, di samping masalah kekecewaan dan perasaan ditekan selama ini. Artinya, bermula dari konfigurasi intersected kemudian berubah menjadi consolidated yang membuka kesadaran konflik dan memungkinkan terjadinya kekerasan kolektif. Adapun dari kacamata budaya politik, berbagai tindak kerusuhan dan tindakan anarkis akhir-akhir ini justru telah disemangati oleh api reformasi yang diterjemahkan secara membabi buta yang terwujud sebagai euforia demokrasi.

Jika dirinci beberapa faktor penyebab timbulnya konflik antar etnis dan antar agama di Indonesia itu antara lain: 1) seberapa jauh tingkat keterbelakangan atau penderitaan kolektif kelompok komunal tersebut dibanding dengan kelompok-kelompok lain; 2) ketegasan identitas kelompok; 3) derajat kohesi dan mobilisasi kelompok; dan 4) kontrol represif oleh kelompok-kelompok dominan. Beberapa alternatifsolusiyangdapatditempuh antaralain:1)perlunya pemahaman dan penerimaan multikulturalisme secara realistis; 2) langkah pembauran dan integrasi semua etnis dalam kehidupan masyarakat; 3) mengelola berbagai perbedaan dalam masyarakat Indonesia yang pluralistik menjadi potensi dalam pembangunan bangsa; 4) peningkatan kemampuan menginterpretasikan dan mengkomunikasikan ajaran agama dengan arif; 5) pentingnya sikap keteladanan para pemimpin agama dalam berinteraksi dengan kaum agama lain.

Dengan demikian, untuk meminimalisasi dan mengeliminasi konflik sosial, pendekatan represif atau keamanan tidaklah tepat. Kini lebih diperlukan pendekatan pemecahan masalah, yang melihat konflik dari berbagai aspeknya, termasuk latar belakangnya, isu sentralnya, dan sebagainya. Pendekatan multikultural merupakan salah satu alternatif yang dapat dimanfaatkan guna mengeliminasi setidak-tidaknya mengurangi konflik sosial yang sering muncul selama ini terutama konflik antaretnis dan antaragama di Indonesia yang masyarakatnya memang multietnis dan multiagama. 


\section{Daftar pustaka}

Alhadar, Alwi, Ivan Dalam Binny Buchori, George Yunus Adicondro. dkk, Ketika Semerbak Cengkih Tergusur Asap Mesiu, Tragedi Kemanusiaan Maluku Dibalik Konspirasi Militer, Kapitalis Birokrat dan Kepentingan Elit Politik, Jakarta: Tapak Ambon, 2001.

Djaelani, Konflik Etnis di Ambon Tinjauan Sosiologi, Tesis UNHAS, Makassar, 2000.

Gerry, Van Klinken, Pelaku Baru Identitas Baru: Kekerasan Antar Suku Pada Masa Pasca Suharto di Indonesia, dalam Dewi Fortuna Anwar (ed), Konflik Kekerasan Internal, Tinjauan Sejarah, Ekonomi-Politik dan Kebijakan di Asia Pasifik, Jakarta: Buku Obor, KITLV-LIPI-LASEMA-CNRS, 2005.

Kastor, Rustam, Konspirasi Politik RMS dan Kristen Menghancurkan Umat Islam, Yogyakarta: Wihdah Press, Cet. I, 2000.

Kimball, Charles, Kala Agama Jadi Bencana, Yogyakarta: Tiarawacana, 2002.

Nurhasim, Moch., dan Ratnawati, Tri, Kapasitas Negara dan Masyarakat Dalam Resolusi Konflik-kekerasan di Ambon, dalam Syafuan Rozi et.al, Kekerasan Komunal; Anatomi dan Resolusi Konflik-kekerasan di Indonesia, Yogakarta: P2P-UPI \& Pustaka Pelajar, 2006.

Shihab, Alwi, Islam Inklusif: Menuju Sikap Terbuka Dalam Beragama, Bandung: Mizan, 1999.

Suadi, Marasabessy, Maluku Baru, Suatu Wujud Masyarakat Maluku Pasca Konflik, Jakarta: PT. Abadi, Cet. I, 2002.

Sinasari, S. Ecip, Bila Cengkeh Tak Berbunga (Membuka Rusuh Ambon), Jakarta: Cahaya Timur, 2003.

Trijono, Lambang, Keluar dari Kemelut Maluku, Refleksi Pengalaman Praktis Bekerja untuk Perdamaian Maluku, Yogyakarta: Pustaka Pelajar, 2001.

et.al, Potret Retak Nusantara, Jakarta: CSPS Books, 2004. 